\title{
Comparing the social values of forest-dependent, provincial and national publics for socially sustainable forest management
}

\author{
by Mark Robson ${ }^{1}$, Alex Hawley ${ }^{2}$ and Dave Robinson ${ }^{3}$
}

A mail survey was conducted of local residents of a forest-dependent region (Fraser Fort George Regional District, $\mathrm{n}=974$ ), provincial (British Columbia, $n=1208$ ) and Canadian ( $n=1672)$ publics to compare their values for forests and preferences for forest management (overall response rate $=45.2 \%$ ). While the local public tended to place a significantly higher $(\mathrm{p}<0.05)$ emphasis on economic values and clearcutting practices relative to provincial and national publics, all publics held quite similar views on forest management overall. All publics support a multi-value/ecosystem management over a single-value/timber management approach to forest management, do not support maximisation of economic returns from timber regardless of the impacts and agree forest managers should be more responsive to local resident values than the values of more distant groups. Responses also reflected a lack of public confidence in government natural resource agencies. Results suggest residents from forest and non forest-dependent communities share similar forest values, that current forest management practices such as clearcutting do not reflect the values of local, provincial or national publics, and that forest managers should be especially responsive to the values of the local public when making forest management decisions.

Key words: social values, forest policy, public participation, socially sustainable forest management

Un sondage postal a été effectué auprès des résidents locaux d'une région dépendante de la forêt (District Fraser Fort George, $\mathrm{n}=974$ ), des habitants d'une province (Colombie-Britannique, $n=1208)$ et des Canadiens $(n=1672)$ afin de comparer leurs valeurs attribuées aux forêts et leurs préférences en matière d'aménagement forestier (taux de réponses global=45,2 \%). Même si les résidents locaux avaient tendance à mettre une emphase significativement plus importante $(\mathrm{p}<0,05)$ sur les valeurs économiques et les pratiques de coupe à blanc par rapport aux résidents provinciaux et les Canadiens, tous ont un point de vue presque similaire sur l'aménagement forestier dans son ensemble. Ils appuient tous un aménagement écosystémique basé sur plusieurs valeurs par rapport à une approche d'aménagement reposant sur une seule valeur comme le bois, ils n'appuient pas la maximisation des retombées économiques en provenance du bois sans regards pour les impacts et ils sont d'accord que les gestionnaires forestiers devraient être plus en mesure de répondre aux valeurs des résidents locaux qu'aux valeurs des groupes plus éloignés. Les réponses ont galement démontré une absence de confiance du public envers les agences gouvernementales responsables des ressources naturelles. Les résultats laissent entendre que les résidents des collectivités qui dépendent et qui ne dépendent pas des forêts partagent des valeurs forestières semblables, que les pratiques d'aménagement forestier comme la coupe à blanc ne reflètent pas les valeurs des résidents locaux, provinciaux ou du Canada, et que les gestionnaires forestiers devraient être principalement en mesure de répondre aux valeurs des résidents locaux lorsqu'ils prennent des décisions en matière d'aménagement forestier.

Mots-clés: valeurs sociales, politique forestière, participation publique, aménagement forestier socialement durable

\section{Introduction}

An essential feature of sustainable forest management is a view in which people are an integral part of the system (Carrow 1994, Galindo-Leal and Bunnell 1995, Kimmons 1995, Koch and Kennedy 1991). People are part of forest ecosystems; they derive material and non-material goods and services from them, they live, work, and play in forests, and their social values,

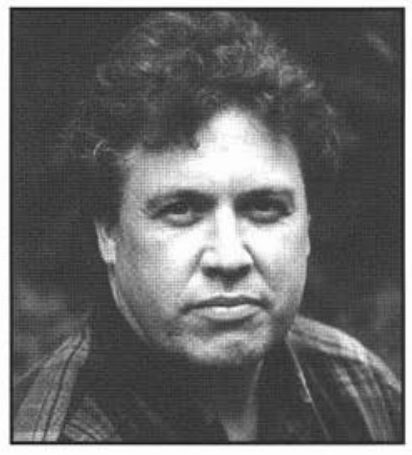

Mark Robson

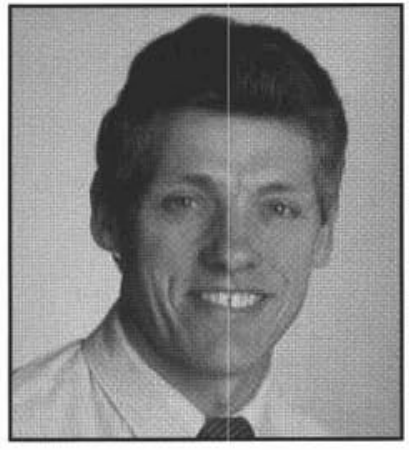

Alex Hawley

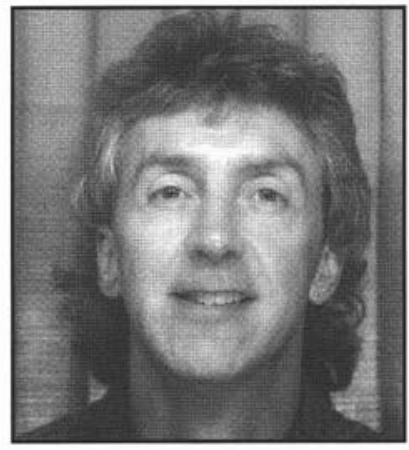

Dave Robinson behaviour, and knowledge of forest ecosystems affect them in both direct and indirect ways (FEMAT 1993).

${ }^{1} \mathrm{PhD}$ candidate, Faculty of Forestry, University of Toronto, 33 Wilcocks St., Toronto, Ontario M5S 3B3. E-mail: mark.robson@utoronto.ca

${ }^{2}$ Chair, Biology, Faculty of Natural Resources and Environmental Studies, University of Northern British Columbia, 3333 University Way, Price George, B.C. V2N 4Z9 E-mail: alex@unbc.ca

${ }^{3}$ Recreation and Tourism Program, Malaspina University College, 900 Fifth St., Nanaimo, B.C. V9R 5S5 Email: robinson@mala.bc.ca
Although the philosophy and practice of forestry recognises the importance of social and biological concerns, traditional forestry thinking has heavily relied upon neo-classical economics when examining societal relationships with forests. The environment and the economy are often presented as two halves of a single whole, but economics is only a part of, not a complimentary half to, the environment. This fallacy - that the economy is the society - is equivalent in the social sphere, to 
the fallacy that timber is the forest in the environmental sphere (Hopwood 1992).

To be socially sustainable, traditional forest management needs to move from its narrow focus on economic objectives (e.g., commodity values) and incorporate a wider range of values and needs into forest management (e.g., commodity as well as amenity, environmental quality, ecological, public use, spiritual, health, heritage and public participation values). The emerging forestry paradigm of sustainable forest management, also known as ecosystem management (Bengston 1994), arose from growing public and professional concern that traditional forest management was no longer socially acceptable due to its failure to incorporate these expanding values into forest management. Dusan Mlinsek, past president of the International Union of Forestry Research Organizations (IUFRO), has also stated that forestry must embrace the postmodern view of the world; that nature is an open, dynamic and totally integrated, and holistic system. Included in this view is the recognition that forestry must pay particular attention to the broader social values of forests if it is to become truly sustainable (Marcin 1995).

Forest managers have traditionally identified the values that people attach to forests through the economic and political systems. However, neither system is effective in expressing all social values, for people's forest values are communicated by three systems. They are communicated by the economic system in the price of wood products, outdoor recreation or summer homes; by the political system in legislation, budget allocation and taxes and grants; and by the social system in people's responses to interviews and questionnaires, the demand for various recreation opportunities, letters to the editor or the shunning of people in a local community because of their forest views (Koch and Kennedy 1991).

The difficulty of identifying and measuring social values communicated by the social system (e.g., ecological and spiritual values) makes it hard to determine how these values are distributed across society, how they change in relative importance over time, how to measure their relative worth vis-a-vis economic values and how they are affected by policy changes and whether such changes are socially optimal. As a result, many of these values have been unaccounted for in forest management (Stankey and Clark 1991). The irony is that many of these are the very values that have become increasingly important in society (FEMAT 1993).

Forest management is a process of integrating the products of science and technology with social values (Hammond and Adelman 1976). Forest management conflicts, in part, are the result of forest management's past focus on the technical aspects of forest manipulation. Despite the impacts forest decisions have on people, their non-market social values have received little attention, at least in any explicit and systematic fashion. However, forest management agencies and corporations are beginning to realize that while a forest practice may be based on sound science and economics, the practice will simply not be socially sustainable in the long run if society judges it to be unacceptable (FEMAT 1993). Recent decisions to replace clearcutting with variable retention silvicultural practices (e.g., MacMillan Bloedel Ltd. and TimberWest Forest Corporation) in British Columbia are examples of this.

Socially sustainable forest management should serve outspoken, unspoken, and future citizens. The outspoken have gen- erally been well represented through consultation processes. Future citizens may best be represented by forest agencies' adherence to "sustainable forest management." The unspoken may best be represented through assessment of their opinions (Dennis 1988, Hale 1993, Shindler et al. 1993). Social science survey research methods can be used to understand people's non-market social values and systematically measure their relative importance (Peterson and Randall 1984). The lack of research on non-market social values means there has been no effective mechanism to capture and provide information about the "highest valued" or "best" non-market use(s) of the forest resource within forest management agencies. Public participation processes may not always be effective at producing information that leads to the development of socially sustainable forest management practices because consultation processes are easily accessed and influenced by specific, organised interest groups, who do not always adequately represent the public (McClosky 1999).

Dennis' (1988) comparison between the public comments received by the Plumas County Land and Resource Management Plan (LRMP) in California and responses to a random survey of local residents is instructive. While mining was clearly opposed in the representative survey of local residents, most miningrelated comments received by the LRMP (18 of 23) advocated increased access to minerals. Clearly, the comments received by LRMP representatives did not reflect the views of local residents.

Survey research has a distinct advantage over other public involvement approaches in that it can address public acceptability from the local to the international level (FEMAT 1993). While surveys cannot supplant more direct forms of public participation, survey research can greatly expand the spectrum of involvement by identifying a broader range of relevant publics with a stake in an issue (e.g., the non-use public as owners of Crown land) (Dennis 1988).

This paper compares results of a social scientific survey of residents in a forest-dependent region (Fraser-Fort George Regional District) and British Columbian and Canadian publics and the values each group attaches to forests and forest management (Robinson et al. 1997). The survey was conducted for the McGregor Model Forest Association (MMFA), a partnership of public and private interests whose purpose is to facilitate the achievement of social, economic and ecological sustainability in the management of the McGregor Model Forest (Forestry Canada 1993). As part of the social analysis programme, the purpose of the survey was to determine the issues and values that the public holds for forests and forest management and to relate these to a decision support system for forest management using the McGregor Model Forest (MMF) as a model of a working forest.

The MMF is an area of publicly-owned Crown land that is contiguous with Northwood Pulp and Timber Limited's Tree Farm License 30 and is used for a wide range of forestry-related, trapping, guide outfitting, recreational and subsistence activities (Forestry Canada 1993). It is located 30 kilometres north-east of Prince George in northern British Columbia and both the MMF and Prince George lie within the Regional District of Fraser-Fort George. Prince George, with a population of 75150 (Statistics Canada 1996), comprises 76 per cent of the Regional District population, and while not considered a rural or small town community by Statistics Canada 
$(1998)^{4}$, is Canada's largest forest-dependent community with $50 \%$ or more of its work force directly employed in the forest sector (Williamson and Shailaja 1996).

\section{Methodology}

The survey instrument consisted of sixty-two questions that addressed the use and importance of forests, forest management preferences, familiarity with forestry issues and respondent socio-demographics, only a sample of which are reported on here. Specifically, the paper compares the demographic profiles of local, provincial and national respondents, respondent views on whom forest managers should be most responsive to when setting forest management goals, the importance and use of forests, forest management priorities and tree harvesting methods. Questions were derived from information obtained through interviews with loggers, trappers, guide outfitters, recreationists, input from local residents, Northwood Pulp and Timber Limited reports, Prince George Land and Resource Management Plan meetings and relevant literature and research results compiled in Robson et al. (1996). The survey instrument underwent four independent reviews and pilot testing to ensure the survey's validity and reliability.

The survey population for the study was people aged eighteen years or older who lived in households with a listed telephone number in the Fraser-Fort George Regional District (for the local sample), British Columbia (for the provincial sample) and Canada (for the national sample). Stratified sampling was used to divide the survey population into three nonoverlapping and independent strata: local, provincial and national. Surveys were mailed to a random sample of households selected from residential telephone directory databases for each strata.

Surveys were prepared in both official languages. French surveys, translated by the Canadian Forest Service, were mailed to Quebec households whose first language was French (as identified by census data). Canadians who received a survey in the wrong language were asked to call the 1-800 number to receive the correct survey version.

The survey design and mail-out procedure followed the standardized method of Salant and Dillman (1994). A cover letter with the 1-800 number, survey, self-addressed, pre-paid postage return envelope and description of the McGregor Model Forest was mailed in February 1996 to: (a) 974 households in the Fraser-Fort George Regional District (local sample), (b) 1208 households in British Columbia (provincial sample), and (c) 1672 households across Canada (national sample). This was followed by a postcard reminder one week later. Four-and-onehalf weeks after the postcard mailing, non-respondents received a follow-up letter with a replacement survey. Finally, a last reminder letter was sent to non-respondents five weeks after the follow-up letter.

All survey returns were coded for data entry to ensure anonymity and confidentiality. The data were scored and analysed using SPSSpc ${ }^{5}$. Descriptive analyses were conducted on the data, and analysis of variance (ANOVA) and Student-Neuman-Keuls tests were conducted to determine whether

${ }^{4}$ Defined as having an urban core of less than 10000 with more than $50 \%$ of the work force commuting to a larger urban centre.

${ }^{5}$ Statistical Program for the Social Sciences for the personal computer, SPSS Inc. 1998. SPSS for Windows Release 9.0.0. Standard Version. differences between national, provincial and local responses to various forest management statements were statistically significant $(\mathrm{p}<0.05)$.

\section{Results and Discussion}

The final response rate was $45.2 \%(44.7 \%, 46.7 \%, 44.1 \%$, respectively, for national, provincial and local respondents). Reference to a standard statistical table suggests there is a $95 \%$ level of confidence (with $+/-0.05$ margin of error) that the results represent the survey population (Salant and Dillman 1994).

The majority of national, provincial and local respondents believed the questionnaire did not exhibit bias $(85.6 \%, 82.1 \%$, $82.5 \%$, respectively). Respondents tended to be male $(70.9 \%$, $66.2 \%$ and $71.1 \%$, respectively) compared to $48.5 \%, 48.8 \%$ and $50.9 \%$ for corresponding census data, and older (e.g., $65.3 \%$, $63.1 \%$ and $56.1 \%$ for respondents 40 years and over, respectively) compared to $55.3 \%, 56.1 \%$ and $48.4 \%$ for corresponding census data (Statistics Canada 1996). Survey results were subsequently weighted to coincide with census data and precisely reflect the relative proportion of gender and age subgroups within each stratum to improve the representativeness of survey results (Salant and Dillman 1994). Data weights were rescaled so that the average weight minimized the unequal probabilities of selection (Statistics Canada 1994). Weighting was based on the assumption that respondents represent the characteristics of non-respondents.

The over-representation of older people and males is attributable to the limitations of using telephone directories since most telephone registrants are probably male who may tend to be homeowners and therefore older. While steps can be taken to encourage random selection, self selection is difficult to control (Statistics Canada 1995) and is a known limitation of mail surveys (Salant and Dillman 1994). The low level of survey bias is attributed to the numerous reviews, pilot testing and subsequent revisions that were made to the survey instrument prior to mailing.

\section{Interest Groups to Which Forest Managers Should be Most Responsive}

The three groups displayed similar patterns with respect to which interest groups forest managers should be most responsive (Table 1). All three groups ranked local affected communities as the group to which forest managers should be most responsive. All three groups ranked national public opinion and international public opinion eighth, and last, respectively, out of nine possibilities. Overall, the three groups tended to give the most emphasis to local affected groups followed by provincial groups, national public opinion and lastly by international public opinion.

Local and provincial respondents placed a higher priority on local affected industry (ranked second and third, respectively, compared with sixth for national respondents). This is possibly because of the greater role of forestry in the lives of Fraser-Fort George's and British Columbia's citizens compared to Canadians as a whole.

The priority assigned to First Nations declined from the national through the provincial to the local level. This is probably due to British Columbian and Fraser-Fort George perceptions that devolution of power from the federal government to First Nations will negatively impact the British Columbia timber industry and the Fraser-Fort George economy. Results were 


\begin{tabular}{|c|c|c|c|c|c|c|}
\hline \multicolumn{7}{|c|}{ Preamble ${ }^{1}$ Who should forest managers be most responsive to when setting forest management goals? } \\
\hline \multirow[b]{3}{*}{ Interest Group } & \multicolumn{6}{|c|}{ Sample Group } \\
\hline & \multicolumn{2}{|c|}{ National } & \multicolumn{2}{|c|}{ Provincial } & \multicolumn{2}{|c|}{ Local } \\
\hline & Rank & Mean & Rank & Mean & Rank & Mean \\
\hline 1. Local affected communities & 1 & 2.7 & 1 & 2.37 & 1 & 1.9 \\
\hline 2. Local affected First Nations groups & 3 & 4.37 & 5 & 4.69 & 6 & 5.11 \\
\hline 3. Local affected industry & 6 & 4.98 & 3 & 4.42 & 2 & 3.63 \\
\hline 4. Local environmental interest groups & 2 & 3.95 & 4 & 4.47 & 4 & 4.66 \\
\hline 5. Provincial or national environmental interest groups & 4 & 4.73 & 6 & 4.92 & 7 & 5.68 \\
\hline 6. Provincial public opinion & 5 & 4.77 & 2 & 4.36 & 3 & 4.5 \\
\hline 7. National public opinion & 8 & 6.16 & 8 & 6.23 & 8 & 6.29 \\
\hline 8. Governmental natural resource agencies & 7 & 5.35 & 7 & 5.18 & 5 & 5.07 \\
\hline 9. International public opinion & 9 & 7.95 & 9 & 7.88 & 9 & 8 \\
\hline
\end{tabular}

${ }^{1}$ The preamble preceded the question in the survey.

Table 2. Mean ranking of six forest uses.

Preamble ${ }^{1}$ Please rank the importance of the following uses of Canada's forests in accordance with your own preferences.

\begin{tabular}{|c|c|c|c|c|c|c|}
\hline \multirow[b]{3}{*}{ Interest Group } & \multicolumn{6}{|c|}{ Sample Group } \\
\hline & \multicolumn{2}{|c|}{ National } & \multicolumn{2}{|c|}{ Provincial } & \multicolumn{2}{|c|}{ Local } \\
\hline & Rank & Mean & Rank & Mean & Rank & Mean \\
\hline 1. Use for wilderness protection. & 3 & 2.81 & 3 & 3.45 & 4 & 4.01 \\
\hline 2. Use as a source of economic wealth and jobs. & 5 & 4.63 & 5 & 4 & 3 & 3.96 \\
\hline 3. Use for maintaining the global ecosystem. & 2 & 2.77 & 2 & 2.82 & 2 & 3.63 \\
\hline 4. Use as a place for recreation and relaxation. & 6 & 4.67 & 6 & 4.72 & 6 & 5.06 \\
\hline 5. Use for protection of Canada's air, water and soil. & 1 & 2.75 & 1 & 2.44 & 1 & 3.5 \\
\hline 6. Use as a place for a variety of animal and plant life. & 4 & 3.34 & 4 & 3.51 & 5 & 4.02 \\
\hline
\end{tabular}

${ }^{1}$ The preamble preceded the question in the survey.

likely influenced by the contentious land claims negotiations between federal and provincial governments and First Nations that were underway during the survey period.

Notable is the ranking of governmental resource agencies (the bodies traditionally empowered to make forest management decisions), which received low to middle rankings (seventh for national and provincial respondents and fifth for local respondents). This finding suggests governmental resource agencies are either not viewed as being appropriate sources of management goals or lack credibility in the eyes of the public. The latter interpretation agrees with other studies that reveal the low regard in which these agencies are held by Canadians (Canadian Council of Ministers of the Environment 1991, Council of Forest Industries 1994). It is interesting to note however, that the credibility of natural resource agencies appears to increase as one moves from the national and provincial to the local level, and closer to the scale at which timber harvesting takes place. Local respondents may have believed that natural resource agencies are more supportive of economically efficient timber harvesting practices such as clearcutting, which tend to be supported more by local rather than provincial and national residents (see Table 4).

\section{Important Uses of Canada's Forests}

National and provincial respondents ranked the importance of six forest uses in an identical manner (Table 2). Protection of Canada's water, air and soil was ranked as the most important use by national and provincial respondents, followed by maintaining the global ecosystem, wilderness preservation, place for a variety of animal and plant life, source of economic wealth and jobs and place for recreation and relaxation. Local respondents ranked economic wealth and jobs higher (third) than did provincial and national publics, both of whom ranked economic wealth and jobs fifth. This is not surprising given the Fraser-Fort George economy's high dependence on timber. However, all respondent groups believed the most important uses of Canada's forests should be for the protection of Canada's air, water and soil and for maintaining the global ecosystem.

National and provincial respondent rankings replicated Canadian responses to the same question in a 1991 survey conducted by Forestry Canada (1992) indicating that Canadians have stable and enduring opinions on important forest uses. This provides an example of how forest values can be monitored to provide resource managers and policy makers with continuing feedback and improved insight on social trends which can assist in the identification of social indicators that might foreshadow shifts in public values (Stankey and Clark 1991). Findings from this study as well as Forestry Canada (1992) and Energy, Mines and Resources Canada (1993) studies indicate that, in general, Canadians value their forests for ecological over economic reasons.

\section{Forest Management Priorities}

All three respondent groups $(87.6 \%, 87.1 \%, 88.5 \%$, respectively, for national, provincial and local samples) disagreed or strongly disagreed that forests should be managed only to produce and harvest timber, and agreed or strongly agreed $(92.5 \%$, $91.3 \%, 96.4 \%$, respectively, for the national, provincial and local samples) that forests should be managed for a wide range of benefits and uses rather than for timber production alone (Table 3). All three groups $(77.7 \%, 71.5 \%, 66.5 \%$, respectively, 
Table 3. Percent of agreement with various forest management priorities.

Preamble ${ }^{1}$ The harvesting of trees is the major economic activity in many of Canada's public forests. Many other uses have been identified. These include commercial uses such as trapping, fiddlehead fern picking, and guiding as well as non-commercial uses such as sport fishing, berry picking, nature interpretation, snowmobiling, hiking, and photography. All these forest uses compete with or complement each other to varying degrees (e.g., the harvesting of trees may influence recreation opportunities and wildlife populations).

\begin{tabular}{|c|c|c|c|c|c|c|c|}
\hline Statement & $\begin{array}{l}\text { Respondent } \\
\text { Group }\end{array}$ & $\begin{array}{c}\text { Strongly } \\
\text { Agree }\end{array}$ & Agree & Neutral & Disagree & $\begin{array}{l}\text { Strongly } \\
\text { Disagree }\end{array}$ & $\begin{array}{c}\text { Don't Know } \\
\text { Responses }\end{array}$ \\
\hline $\begin{array}{l}\text { 1. Forests should be managed only to } \\
\text { produce and harvest timber. }\end{array}$ & $\begin{array}{l}\text { National } \\
\text { Provincial } \\
\text { Local }\end{array}$ & $\begin{array}{l}1.1 \\
1.8 \\
1.5\end{array}$ & $\begin{array}{l}4.4 \\
3.5 \\
4.1\end{array}$ & $\begin{array}{l}5.7 \\
6.8 \\
5.5\end{array}$ & $\begin{array}{l}38.4 \\
42.0 \\
45.5\end{array}$ & $\begin{array}{l}49.2 \\
45.1 \\
43.0\end{array}$ & $\begin{array}{l}1.2 \\
0.8 \\
0.4\end{array}$ \\
\hline $\begin{array}{l}\text { 2. Forests should be managed for a wide } \\
\text { range of benefits and users rather than for } \\
\text { timber production alone. }\end{array}$ & $\begin{array}{l}\text { National } \\
\text { Provincial } \\
\text { Local }\end{array}$ & $\begin{array}{l}49.1 \\
46.8 \\
51.4\end{array}$ & $\begin{array}{l}43.4 \\
44.5 \\
45.0\end{array}$ & $\begin{array}{l}4.2 \\
4.6 \\
2.7\end{array}$ & $\begin{array}{l}1.5 \\
2.4 \\
1.0\end{array}$ & $\begin{array}{l}0.6 \\
0.6 \\
0.0\end{array}$ & $\begin{array}{l}1.2 \\
1.1 \\
0.0\end{array}$ \\
\hline $\begin{array}{l}\text { 3. Maintaining the economy of logging } \\
\text { communities is more important than } \\
\text { preserving the forest for other uses } \\
\text { and values. }\end{array}$ & $\begin{array}{l}\text { National a } \\
\text { Provincial a }^{\text {a }} \\
\text { Local }^{\mathrm{b}}\end{array}$ & $\begin{array}{l}1.8 \\
2.1 \\
1.6\end{array}$ & $\begin{array}{r}6.3 \\
7.5 \\
13.0\end{array}$ & $\begin{array}{l}13.0 \\
17.2 \\
18.9\end{array}$ & $\begin{array}{l}45.8 \\
42.8 \\
46.1\end{array}$ & $\begin{array}{l}31.9 \\
28.7 \\
20.4\end{array}$ & $\begin{array}{l}1.3 \\
1.8 \\
0.0\end{array}$ \\
\hline $\begin{array}{l}\text { 4. The present rate of harvesting trees is } \\
\text { too great to sustain the forest for other } \\
\text { values and uses. }\end{array}$ & $\begin{array}{l}\text { National }{ }^{\mathrm{a}} \\
\text { Provincial }^{\mathrm{a}} \\
\text { Local }^{\mathrm{b}}\end{array}$ & $\begin{array}{l}22.1 \\
21.0 \\
17.1\end{array}$ & $\begin{array}{l}31.9 \\
33.0 \\
30.7\end{array}$ & $\begin{array}{r}9.0 \\
8.7 \\
12.0\end{array}$ & $\begin{array}{r}7.9 \\
11.7 \\
19.6\end{array}$ & $\begin{array}{l}3.2 \\
3.0 \\
6.5\end{array}$ & $\begin{array}{l}26.0 \\
22.7 \\
14.0\end{array}$ \\
\hline $\begin{array}{l}\text { 5. Forest management should try to } \\
\text { minimize impacts on traditional rural } \\
\text { ways of life (e.g., hunting and fishing } \\
\text { for food). }\end{array}$ & $\begin{array}{l}\text { National } \\
\text { Provincial } \\
\text { Local }\end{array}$ & $\begin{array}{l}19.1 \\
15.1 \\
19.5\end{array}$ & $\begin{array}{l}44.5 \\
49.6 \\
45.7\end{array}$ & $\begin{array}{l}15.8 \\
17.7 \\
16.5\end{array}$ & $\begin{array}{r}12.1 \\
9.1 \\
13.5\end{array}$ & $\begin{array}{l}3.9 \\
3.3 \\
2.0\end{array}$ & $\begin{array}{l}4.6 \\
5.2 \\
2.9\end{array}$ \\
\hline
\end{tabular}

for national, provincial and local samples) disagreed or strongly disagreed that maintaining the economy of logging communities is more important than preserving the forest for other uses and values. The local respondent group agreed with the latter statement to a significantly greater extent $(\mathrm{p}<0.05)$ than national and provincial groups.

The item "the present rate of harvesting is too great to sustain the forest for other values and uses" generated a notably larger number of "don't know" responses (range $14.0 \%$ to $26.0 \%$ ) than did the other statements relating to forest management priorities. While all three groups $(54.0 \%, 54.0 \%, 47.8 \%$, respectively, for national, provincial and local samples) agreed or strongly agreed with this statement, the local group agreed with the statement to a lesser extent than the provincial and national groups $(\mathrm{p}<0.05)$. National, provincial and local respondents $(63.6 \%, 64.7 \%, 65.2 \%$, respectively) agreed or strongly agreed that forest management should try to minimize impacts on traditional rural ways of life, such as hunting and fishing for food.

These findings suggest that Canadian, British Columbian and Fraser-Fort George residents support a multi-value/ecosystem over a single-value/timber management approach to forest management and parallel results from a similar study of Oregon and U.S. residents (Shindler et al. 1993). The lower level of disagreement by local respondents compared to provincial and national respondents, that logging economies were more important than forest preservation, was probably due to the Fraser-Fort George economy's greater dependence on timber. British Columbia residents may have been less adamant on this point than Canadian residents for the same reason.

Fraser-Fort George residents may not have believed as much as Canadian and British Columbian residents that the rate of logging was too great to sustain the forest for other uses and values because Fraser-Fort George residents were more accustomed to the level of logging. The lower rate of "don't know" responses for the local public suggests Fraser-Fort George residents are more confident about their views, possibly because they have more direct contact with logging activities than Canadians and British Columbians in general. Nevertheless, the relatively high rate of "don't know" responses overall suggests many respondents in all three groups were unsure whether the rate of logging was too great.

\section{Tree Harvesting Methods}

National, provincial and local respondents were generally negative about clearcutting and positive about partial cutting (Table 4). National, provincial and local respondents agreed that clearcutting has negative visual effects, leads to overcutting, has negative environmental effects and is not as good as partial cutting for maintaining other forest uses and values. Local respondents viewed clearcutting more favourably and partial cutting less favourably in comparison to provincial and national respondents $(\mathrm{p}<0.05)$.

A higher percentage of national, provincial and local respondents agreed or strongly agreed that clearcutting maximizes logging efficiency $(48.0 \%, 46.4 \%, 63.3 \%$, respectively) than disagreed or strongly disagreed with the statement $(20.5 \%, 22.7 \%, 16.5 \%$, respectively), although this item generated a large number $(19.8 \%, 19.8 \%, 12.2 \%$, respectively) of “don't know" responses (Table 4). Local respondents agreed with the statement to a significantly greater extent $(\mathrm{p}<0.05)$ than national and provincial respondents.

Presumably, Fraser-Fort George residents were more supportive of clearcutting and less supportive of selective cutting than Canadian and British Columbian residents due to their 


\section{Table 4. Percent of agreement with statements relating to tree harvesting methods.}

Preamble ${ }^{1}$ Tree harvesting methods depend upon the physical environment and the biological makeup of the area. Harvesting methods range from clearcutting to partial cutting. Clearcutting is the removal of all trees within a cutting area and is the dominant logging practice. Partial cutting is the removal of certain trees selected on the basis of age, species, or health.

\begin{tabular}{|c|c|c|c|c|c|c|c|}
\hline Statement & $\begin{array}{l}\text { Respondent } \\
\text { Group }\end{array}$ & $\begin{array}{l}\text { Strongly } \\
\text { Agree }\end{array}$ & Agree & Neutral & Disagree & $\begin{array}{l}\text { Strongly } \\
\text { Disagree }\end{array}$ & $\begin{array}{l}\text { Don't Know } \\
\text { Responses }\end{array}$ \\
\hline \multirow{3}{*}{$\begin{array}{l}\text { 1. Tree harvesting methods should maximize } \\
\text { economic returns regardless of their impact } \\
\text { on other forest values and uses. }\end{array}$} & National & 3.9 & 4.6 & 3.8 & 34.5 & 50.1 & 3.0 \\
\hline & Provincial & 2.9 & 3.0 & 4.7 & 36.0 & 49.0 & 4.5 \\
\hline & Local & 3.1 & 5.4 & 4.4 & 41.5 & 43.8 & 1.9 \\
\hline \multirow[t]{3}{*}{ 2. Clearcutting has negative visual effects. } & National $^{\text {a }}$ & 48.2 & 35.5 & 3.4 & 5.8 & 3.2 & 3.9 \\
\hline & Provincial a & 51.9 & 32.7 & 3.9 & 4.7 & 3.6 & 3.2 \\
\hline & Local $^{b}$ & 36.2 & 44.9 & 6.9 & 8.4 & 3.0 & 0.6 \\
\hline \multirow[t]{3}{*}{ 3. Clearcutting maximizes logging efficiency. } & National a & 16.7 & 31.3 & 11.8 & 12.8 & 7.7 & 19.8 \\
\hline & Provincial $^{a}$ & 13.0 & 33.4 & 11.0 & 15.5 & 7.2 & 19.8 \\
\hline & Local $^{b}$ & 16.6 & 46.7 & 8.0 & 10.9 & 5.6 & 12.2 \\
\hline \multirow[t]{3}{*}{ 4. Clearcutting leads to overcutting. } & National a & 37.5 & 39.5 & 6.3 & 6.5 & 0.8 & 9.5 \\
\hline & Provincial $^{a}$ & 34.9 & 37.5 & 7.4 & 5.7 & 2.7 & 11.8 \\
\hline & Local $^{b}$ & 20.6 & 36.0 & 10.7 & 20.1 & 5.3 & 7.3 \\
\hline \multirow[t]{3}{*}{ 5. Clearcutting mimics natural forest fires. } & National & 7.7 & 19.7 & 10.5 & 23.3 & 15.6 & 23.2 \\
\hline & Provincial & 6.6 & 15.7 & 12.5 & 25.4 & 16.3 & 23.5 \\
\hline & Local & 4.3 & 25.3 & 13.5 & 32.0 & 13.4 & 11.7 \\
\hline \multirow{3}{*}{$\begin{array}{l}\text { 6. Clearcutting has negative environmental } \\
\text { effects. }\end{array}$} & National $^{\text {a }}$ & 41.8 & 36.1 & 3.3 & 6.7 & 5.3 & 6.8 \\
\hline & Provincial $^{a}$ & 38.0 & 34.1 & 6.2 & 7.4 & 4.8 & 9.5 \\
\hline & Local $^{b}$ & 19.4 & 37.5 & 12.2 & 19.7 & 5.8 & 5.4 \\
\hline \multirow{3}{*}{$\begin{array}{l}\text { 7.Partial cutting is better than clearcutting } \\
\text { for maintaining other forest uses and values. }\end{array}$} & National a & 47.8 & 36.1 & 4.3 & 3.6 & 1.6 & 6.7 \\
\hline & Provincial ${ }^{a}$ & 38.7 & 44.6 & 5.5 & 3.0 & 0.8 & 7.4 \\
\hline & Local $^{b}$ & 28.1 & 41.7 & 12.2 & 9.6 & 1.9 & 6.6 \\
\hline
\end{tabular}

${ }^{1}$ The preamble preceded the statements in the survey.

$a b c$ Respondent groups with different letters have means that are significantly different. ${ }^{*} \mathrm{p}<0.05$

more direct dependence on the more economically efficient clearcutting method. Fraser-Fort George residents' higher level of agreement that clearcutting maximizes logging efficiency and lower rate of “don't know" responses reinforces this argument.

All three groups disagreed that tree harvesting methods should ignore impacts on other values to maximize economic returns $(84.6 \%, 85.0 \%, 85.3 \%$, respectively, for national, provincial and local samples). A larger proportion of national, provincial and local groups disagreed or strongly disagreed that clearcutting mimics natural forest fires $(38.9 \%, 41.7 \%, 45.4 \%$, respectively) than agreed or strongly agreed with the statement $(27.4 \%, 28.9 \%, 29.6 \%$, respectively), but this item had a large number of “don't know" responses $(23.2 \%, 23.5 \%$, $11.7 \%$, respectively). It is noteworthy that Canadian, British Columbian and Fraser-Fort George residents tended not to believe clearcutting mimicked natural forest fires, although there was a relatively high rate of "don't know" responses. This is one of the major arguments used to defend clearcutting (Smith et al.1997).

These findings further reinforce the notion that Canadian, British Columbian and Fraser-Fort George residents preferred a multi-value/ecosystem to a single-value/timber management approach to forest management. The generally negative view of clearcutting is also consistent with Forestry Canada's $(1990,1992)$ studies and reveals Canadians' stable and enduring disagreement with the practice.

\section{Conclusion}

Overall, Canadian, British Columbian and Fraser-Fort George Regional District residents held quite similar views on forest management. While the local public tended to place a significantly higher emphasis on economic values and clearcutting practices, all groups supported a multi-value/ecosystem management over a single-value/timber management approach to forest management, did not support maximisation of economic returns from timber regardless of the impacts and agreed that forest managers should be more responsive to local resident values than the values of more distant groups.

The similarity between the forest values of the largely non forest-dependent, urban-dominated populations of Canada and British Columbia and the highly forest-dependent but urban-dominated Fraser-Fort George population suggests the forest values of residents of forest and non forest-dependent communities may not be as divergent as is widely believed. This finding appears to be supported by previous Forestry Canada $(1990,1992)$ studies which reveal that urban and rural Canadians hold generally similar forest management values and that this similarity is increasing.

Further evidence indicates that loggers and residents of forest-dependent communities hold forest values traditionally associated with urban residents (e.g., ecological and environmental quality values). In Dunk's (1994) interviews with 45 loggers in northwestern Ontario, environmental quality and nostalgia for a more natural forest without clearcutting were 
widespread concerns. In a communications needs assessment conducted for the Council of Forest Industries (1994) in northern B.C., unsustainable timber harvesting practices, the need for local control and the need for land use decisions to incorporate the importance of non market values in management decisions were identified as the first, second and third most important forest management issues for forest-dependent community leaders. The similarity between the forest values of forest and non forest-dependent communities is supported by Dasgupta's (1988) analysis of rural social change in Canada where rural residents are posited to have adopted many of the values of urban Canada due to technological developments (e.g., telecommunication networks, automobiles, etc.) which facilitate increased interaction with urban people.

These conclusions contradict the widely held view that residents of forest and non forest-dependent communities are deeply divided over forest management policy. As to why this perception continues to exist despite substantial social scientific evidence to the contrary is difficult to judge. The answer may lie in the political processes used by forest management agencies to solicit public input.

Round table processes, while broadly soliciting input, often receive it from narrow, unrepresentative and often polarized special interest groups. These groups frequently express their opinions in loud and powerful language and so their polarized views become well known. Like Dennis' (1988) example of the Plumas County LRMP, powerful and well-resourced industrial groups often come to dominate local round tables in forest-dependent communities and, as a result, are perceived to represent the views of local residents. Likewise, the dissenting views of outspoken, urban-based environmental groups are often perceived to represent the views of urban residents. As both groups vie for media attention, the complexity of the issue is reduced to short sound bites that represent the conflict in stereotypical terms. Residents of forest-dependent communities are cast as exclusively pro-timber and anti-environment, while urban residents are cast as exclusively pro-environment and anti-timber. As a result, the broader views of forestdependent community and urban residents are overlooked.

This study together with Forestry Canada $(1990,1992)$ and EMR Canada (1993) studies reveal the emergence of stable and enduring beliefs among Canadians regarding socially sustainable forest management. Over a seven-year period from 1989 to 1996, the practice of clearcutting has not been socially acceptable to Canadians and from 1991 to 1996 Canadians continued to value forests for environmental before economic reasons. Since clearcutting is still the dominant harvesting practice in Canada (Canadian Forest Service 1997), it is not surprising that Canadians view resource management agencies as either inappropriate sources of management goals or lacking credibility. This lack of responsiveness reinforces Carrow's (1994) belief that management of Canada's Crown forests has not reflected the values of the public and Hessing and Howlett's (1997) assertion that resource and environmental policy-making in Canada tends to consider only policy instruments within traditional frameworks rather than the possible goals of policy such as socially sustainable forest management.

The future success of forest policy makers and managers will be determined by how well they are able to translate increasingly important non market values into management plans and policies that accommodate a broad and diverse set of forest val- ues. Traditionally, forest officials have identified people's social values in economic terms and through public participation processes that best elucidate the values of outspoken and wellresourced interest groups. The non market social values of the broader public have thus been overlooked.

This research demonstrates how social science research can be used to identify and measure the public's "highest valued" or "best" non-market use(s) of the forest resource. It provides information on how non market social values are distributed across society (e.g., from forest-dependent to non forestdependent communities), how they have changed in relative importance over time (e.g., from 1989 to 1996), how they rank relative to economic values (e.g., relative importance of nontimber values vis-a-vis maintenance of the economy of logging communities), how they may be affected by future policy changes and whether such changes will be socially optimal (e.g., introduction of policies that promote ecosystem management and reduction of clearcutting). This information can be tracked to provide forest policy makers and managers with information on social trends that can assist in the identification of social indicators that might foreshadow shifts in public values. It can provide forest officials with a more complete understanding of their constituency, balance values expressed through markets and public participation processes, and facilitate the development of more socially sustainable forest management policies.

There are no easy answers to forest conflicts. However, a key starting point is recognition that forest management conflicts are not the result of insufficient scientific understanding. Rather, forest management conflicts are social problems that demand social solutions that address the values that society seeks to satisfy. The role of science is to facilitate decision makers' and the public's understanding of the implications of choosing one forest management option over another, but science cannot make these difficult value choices (FEMAT 1993).

Society demands a wide range of goods and services from the forest. Much of the knowledge and many of the practices of traditional forest management are crucial to meeting these societal demands. However, there is clearly a need for different approaches that respond to demands for a sustainable, multivalue approach to forest management (Stankey and Clark 1991).

\section{Acknowledgements}

We would like to thank the McGregor Model Forest Association for funding the research and the Canadian Forest Service for translating the survey instrument. We would like to thank Linda Kupp and Ed Stafford, our research assistants, as well as the reviewers who provided many useful insights and suggestions. Finally, we would like to thank the many Canadians who took the time to complete and return the survey.

\section{References}

Bengston, D.N. 1994. Changing Forest Values and Ecosystem Management. Society and Natural Resources. 7(6): 515-533.

Canadian Council of Ministers of the Environment. 1991. 1991 Environmental Scan: National and International Environmental Issues. Prepared by Resource Futures International and Institute for Research on Public Policy. 102p. + appendices.

Canadian Forest Service. 1997. The State of Canada's Forests Learning from History 1996-1997. Natural Resources Canada, Ottawa. Carrow, R. 1994. Integrated Resource Management in Canada - A 
Case Study of Unrealized Potential. For. Chron. 70(1): 19-21. Council of Forest Industries. 1994. A Communications Needs Assessment of Communities in the Northern Interior Lumber Sector of COFI. Prepared by Bonderud Public Relations, Prince George. 23p. + addendum.

Dasgupta, S. 1988. Rural Canada: Structure and Change. The Edwin Mellen Press,.Queenston, Ontario. 215p.

Dennis, S. 1988. Incorporating Public Opinion Surveys in National Forest Land and Resource Planning. Society and Natural Resources. 1: 309B316.

Dunk, T. 1994. Talking about Trees: Environment and Society in Forest Workers' Culture. The Canadian Review of Sociology and Anthropology. 31: 14-34.

Energy, Mines and Resources (EMR). 1993. National Public Opinion Survey on Natural Resources. Prepared by Corporate Research Associates Inc., Ottawa. 55 p.

Forest Ecosystem Assessment Management Team (FEMAT). 1993. Forest Ecosystem Management: An Ecological, Economic and Social Assessment Report of the Forest Ecosystem Management Team. 2 vols. U.S. Government Printing Office, Washington D.C.

Forestry Canada. 1990. 1989 National Survey of Canadian Public Opinion on Forestry Issues. Prepared by Environics Research Group Limited, Ottawa.

Forestry Canada. 1992. 1991 National Survey of Canadian Public Opinion on Forestry Issues. Prepared by Environics Research Group Limited, Corporate Research Associates Inc. and CROP Inc. Ottawa. 34p. + appendix.

Forestry Canada. 1993. McGregor Model Forest Network. Ministry of Supply and Services, Canada. Pamphlet.

Galindo-Leal, C. and F.L. Bunnell. 1995. Ecosystem Management: Implications and Opportunities of a New Paradigm. For. Chron. 71(5): 601-606.

Hale, E. 1993. Successful Public Involvement. Journal of Environmental Health. 5b (4): 17-19.

Hammond, K.R. and L. Adelman. 1976. Science, Values and Human Judgement. Science. 194: 389-396.

Hessing, M. and M. Howlett. 1997. Canadian Natural Resource and Environmental Policy: Political Economy and Public Policy. UBC Press, Vancouver, B.C. 338 p.

Hoberg, G. 1996. The Politics of Sustainability: Forest Policy in British Columbia. In R.K. Carty (ed.). Politics, Policy and Government in British Columbia. pp. 272-289. UBC Press, Vancouver, B.C.

Hopwood, D. 1992. Reductionism and Holism in the Study of Environment and Society: Some Thought Towards an Ethic of Sustainable Forestry. Forest Planning Canada. 9(1): 13-20.
Kimmons, J.P. 1995. Sustainable Development in Canadian Forestry in the Face of Changing Paradigms. For. Chron. 71(1): 33-40.

Koch, N.E. and J.J. Kennedy. 1991. Multiple-use Forestry for Social Values. Ambio. 20(7): 330-333.

Marcin, T.C. 1995. Integrating Social Sciences into Forest Management Research. J. For. 93(11): 29-33.

McClosky, M. 1999. Local Communities and the Management of Public Forests. Ecology Law Quarterly. 25(4): 624-629.

Peterson, G.L. and A. Randall. (eds.). 1984. Valuation of Wildland Resource Benefits. Westview Press Inc., Boulder, Colorado.

Robson, M., D. Robinson and A. Hawley. 1996. Identifying the Community of Interests Related to the McGregor Model Forest: Who is it That Cares About the McGregor Model Forest and What is it That They Care About? 3 vols. Prince George: McGregor Model Forest Association. $155 \mathrm{p}$.

Robinson, D., M. Robson and A. Hawley. 1997. Social Valuation of the McGregor Model Forest: Assessing Public Opinion on Forest Values and Forest Management Results of the 1996 Canadian Forest Survey. McGregor Model Forest Association, Prince George. 177 p. Salant, P. and D.A. Dillman. 1994. How to Conduct Your Own Survey. John Wiley \& Sons, Inc. Toronto, Ontario. 232p.

Shindler, B., P. List and B. Steel. 1993. Managing Federal Forests Public Attitudes in Oregon and Nationwide. J. For. 91(7): 36B42.

Smith, D.M., B.C. Larson, M.J. Kelty and P.M.S. Ashton. 1997. The Practice of Silviculture - Applied Forest Ecology 9th ed. John Wiley \& Sons Inc..Toronto, Ontario. 537 p.

Stankey, G.H. and R.N. Clark. 1991. Social Aspects of New Perspectives in Forestry: A Problem Analysis. The Gifford Pinchot Institute for Conservation Monograph Series. Greytowers Press, Milford, Pennsylvania. 33 p.

Statistics Canada. 1994. The Importance of Wildlife to Canadians: A User's Guide to the Methodology of a 1991 Survey. Special Report \#17. Minister of Supply and Services Canada, Ottawa. 172 p. Statistics Canada. 1995. Introduction to Survey Research: Sample Design (Participants' Workbook). Minister of Supply and Services Canada, Ottawa. 35 p.

Statistics Canada. 1996. Nation Series Package No. 1: Single Years of Age and Sex (data products: The Nation: 1996 Census of Population). CD-ROM. Minister of Supply and Services Canada: Ottawa. Statistics Canada. 1998. Rural and Small Town Canada Analysis Bulletin. 1(1):1-12.

Williamson, T. and A. Shailaja. 1996. Analysis of the Contribution of the Forest Industry to the Economic Base of Rural Communities in Canada. Working Paper No. 43. Industry, Economics and Programs Branch. Natural Resources Canada, Canadian Forest Service, Ottawa. 